\title{
Brazil's climate modellers are set to go global
}

\section{Supercomputer will drive model to analyse effects of wildfire on world climate.}

\section{BY JEFF TOLLEFSON}

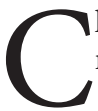
limate modellers in Brazil are getting ready to unleash a silicon god.

Named Tupã, after a native South American god of thunder, a Cray XT6 supercomputer is gradually coming to life at Brazil's Centre for Weather Forecast and Climate Studies in Cachoeira Paulista, northeast of São Paulo. By late November, when the machine is expected to be fully operational, it will have a peak processing speed of more than 244 teraflops, ranking it among the top 25 most powerful computers in the world. So great is Tupãs thirst for electricity that it will only run at $20 \%$ capacity until a new power source comes online in February 2011.

Working with their counterparts at the Hadley Centre in Exeter, UK, Brazilian modellers will use Tupã to apply their expertise on the release of black carbon and other aerosols from Amazonian fires to the global climate-modelling arena. "We want to bring knowledge of the Amazon into our model, and that will then be an original contribution," says Paulo Nobre, a senior modeller with the National Institute for Space Research (INPE).

Brazilian science minister Sergio Rezende proposed the initiative three years ago, as a strategic investment intended to nurture a relatively small climate-modelling team and help bolster Brazilian climate science on the international stage. Tupã builds on several decades of effort to develop a weather- and climatemodelling capacity; in time, the supercomputer could help to earn Brazil a place in the small club of nations that contributes global climate-modelling expertise to the Intergovernmental Panel on Climate Change (IPCC). China has paved the way among developing countries, but Brazil would be the first country

\section{$\rightarrow$ NATURE.COM} For more on climate modelling and the Hadley Centre see: go.nature.com/nlfkgx modelling expertise that will help Brazilian scientists answer questions about national climate impacts and adaptations, says Henrique de Brito Cruz, scientific director of the São Paulo Research Foundation, which partnered with the federal Ministry of Science to fund the US\$30-million project. "What we want is for them to be able to develop and perfect their own models so that they can focus on questions and regions that are especially relevant for Brazil,” says Brito Cruz. "To study

vegetation and climate, says Betts, and fire plays an important role.

Tupã will come online too late to participate fully in all the modelling scheduled for the IPCC's fifth assessment. Instead, says Nobre, the team will work with the Hadley Centre on century-scale climate simulations, while conducting regional modelling exercises that explore global warming's potential impacts throughout Brazil in more depth. Although hosted at the INPE, Tupã will serve as a national supercomputer. The INPE is setting up a committee to analyse research proposals and allocate computer time; researchers will use the machine to assess a broad array of weather and climate issues.

Of particular interest is the potential impact of climate change on the Amazon region. The Hadley Centre's simulations have found that a warming of surface waters in the northern equatorial Atlantic Ocean could shift precipitation northwards, resulting in a significant dieback of the rainforest later this century. That is consistent with a major Amazon drought in 2005 and a second one that is under way at present. Brazilian climate modellers have

regional issues, you need a global model."

Rather than starting from scratch, the Brazilian approach has been to piggyback on the Hadley Centre's Global Environmental Model (HadGEM2_ES) while adding new features that reflect the complex interactions between the rainforest and the atmosphere above it. The resulting model could be the first to incorporate a detailed treatment of aerosol emissions from fire, enabling UK and Brazilian scientists to probe how the climate system responds to hot plumes carrying black carbon and other chemical compounds produced by fires in the Amazon and around the world.

"It is a tremendously exciting step forward," says Richard Betts, who heads climate-impact modelling at the Hadley Centre. The IPCC's fifth assessment includes a systematic analysis of various land-use scenarios that will allow scientists to explore the interactions between sphere, apart from Australia, to develop such a capacity.

But the overriding goal is to develop domestic also begun collaborating with colleagues in South Africa and India and plan to host a new Earth system modelling workshop for scientists from all three countries next summer.

Francois Engelbrecht, an atmospheric modeller with South Africa's Council for Scientific and Industrial Research in Pretoria, says that Brazil's programme has helped inspire similar efforts to build up a global climate-modelling capacity in his country.

"It's a very good example of what can be achieved in a smaller but very focused modelling group," Engelbrecht says. -

\section{CORRECTION}

In the News Feature 'The century of the city' (Nature 467, 900-901; 2010), the population of Dhaka in Bangladesh in 2025 is expected to be 18.7 million, not 18.7 billion. 